\title{
Adoption of Industry 4.0 Technologies and Company Competitiveness: Case Studies from a Post-Transition Economy
}

\author{
Marta Götz \\ Associate Professor, Department of Business and International Relations, m.gotz@vistula.edu.pl \\ Vistula University, ul. Stokłosy 3, 02-787 Warszawa, Poland \\ Barbara Jankowska \\ Associate Professor at the Department of International Competitiveness, barbara.jankowska@ue.poznan.pl \\ Poznań University of Economics and Business; al. Niepodległości 10, 61-875 Poznań, Poland
}

\begin{abstract}
$\mathrm{M}$ anufacturers face increased cost pressures and market volatility. Product life cycles are getting shorter. Production has to be faster and increasingly local. The acceleration of «time-to-market» could happen thanks to the solutions of Industry 4.0 (I4.0), with supply chains morphing into highly adaptive networks with integrated entities. In this paper, we seek to explore the potential impact of I4.0's adoption upon the competitiveness of the firms (foreign subsidiaries among others) and ask about the nature of modernization as part of the global value chain in which the enterprise operates. Our research based on four case studies reveals that the competitive

advantage of a firm could be modified in the era of Industry 4.0 as a result of a sector's transformation and changing relationships with partners. These findings correspond with the literature stressing the uncertainty and complexity of the digital economy in general, as well as difficulties with the precise measurement of the expected benefits. The fourth industrial revolution emphasizes "the race to the top", giving priority to quality rather than to cost reduction as a method of improving competitiveness and, since it implies the emergence of connected companies, truly linked to one another, the disappearance of clear boundaries between them.
\end{abstract}

eywords: Industry 4.0; digital technologies; post-transition economy; manufacturing; case study; competitiveness; product life cycle
Citation: Götz ., Jankowska B. (2020) Adoption of Industry 4.0 Technologies and Company Competitiveness: Case Studies from a Post-Transition Economy. Foresight and STI Governance, vol. 14, no 4, pp. 61-78.

DOI: $10.17323 / 2500-2597.2020 .4 .61 .78$ 
$\mathrm{M}$ anufacturers face increased cost pressure and market volatility. Product life cycles are getting shorter. Production must be faster and increasingly local. New business models based on manufacturing as a service (MaaS) have emerged [Aquilante et al., 2016]. The acceleration of "time-to-market" could happen thanks to the solutions of Industry 4.0 (I4.0), with supply chains morphing into highly adaptive networks with integrated entities. What is different about the current revolution from previous ones is that it has been initiated in society and has influenced industry rather than other way round - "its main drivers are the invention of social networks and smart devices (...) this development of interconnectivity pushes into the industrial sector today" [Schuh et al., 2014]. The results obtained by Edquist et al. [Edquist et al., 2019] demonstrate that a 10-percentage-point increase in the growth of Internet of Things (IoT) connections (regarded as one of the major I4.0 technologies) per inhabitant is associated with a 0.23 -percentagepoint increase in TFP growth. Additionally, drawing on a growth-accounting framework, these authors showed that the potential global annual average contribution to growth by the IoT of $0.99 \%$ per annum between 2018 and 2030.

In this paper, we seek to identify how much I4.0 has been adopted by the companies in the study, how much they understand the concept of I4.0, and thus, we aim to demonstrate the potential impact of I4.0's adoption upon the competitiveness of the firms. We also attempt to ask about the nature of modernization as part of the global value chain in which the enterprise operates.

\section{Premises of Industry 4.0}

Industry 4.0 represents a smart manufacturing networking concept that "marries physical production and operations with smart digital technology, machine learning, and big data to create a more holistic and better-connected ecosystem for companies that focus on manufacturing and supply chain management." 1 The term I4.0 emerged in Germany during the Hannover Fair (originally - Industrie 4.0). However, other countries adopted slightly different terminology - "Industrial Internet" in the United States and "Internet + " in the People's Republic of China [Wang et al., 2016]. I4.0 is founded upon four key sub-concepts: Cyber-Physical Systems (CPS), the Internet of Things, the Internet of Services, and Smart Factories [Hermann et al., 2015]. Since from a technical point of view much of I4.0 is about digitization and automation, the transformation of contemporary business models is to be expected. Such a transformation has already begun and is reflected in the development of digital value chains [Lasi et al., 2014]. This has all happened since companies began exploiting the nine technology advances which are the backbone of I4.0: Big Data and Ana- lytics; Autonomous Robots; Simulation; Horizontal and Vertical System Integration; The Industrial Internet of Things; Cybersecurity, the Cloud; Additive 3D Manufacturing; and Augmented Reality [Rüßmann et al., 2015]. Smart technologies used in the manufacturing processes are translated into holistic digitalized models of products and factories (digital factory) [Lasi et al., 2014; Lucke et al., 2008] (see examples at Table 1).

Various studies confirm that companies face significant challenges in managing their digital transformation. Based on a survey of nearly 200 large and medium-sized Slovenian companies, Štemberger et al. [Štemberger et al., 2019] showed that there are six different successful organizational patterns. The most successful turned out to be the business-IT partnership, where the CEO and the IT department are jointly responsible for the digital transformation. The results obtained also demonstrate the need for orchestrating the activities and actors of digital transformations.

I4.0 stands for a multidimensional system of value creation covering numerous terms in the management of organizational as well as technological and manufacturing-related variables that can be classified and where several interdependencies between them may be identified [Nosalska et al., 2019]. This transforms current business models since, as noted by [Kagermann et al., 2013], it requires companies to reorganize the context of their operations and their own strategic capabilities. Thus, actions in both directions- externally and internally oriented efforts - are needed.

The complexity of I4.0 comes in many forms and shapes. The current understanding of the nature of Industry 4.0 is still blurred with various uncertainties arising, which leads to different scenarios seeming equally possible today [Culot et al., 2020]. It can be depicted by the holistic digitalized models - business models which use VR, AR, or digital twins but at the same time incorporate digital change into HR or broader management processes, not merely in production. I.40 more than ever before highlights the importance of interdependencies between the structure of the industry and the performance of companies. Mutual interlocking relations between processes going on within the sectors and those occurring at the firm level turned out to be critical for the successful implementation of digital technologies due the integrative nature of I4.0 solutions [Kagermann et al., 2013; Rüßmann et al., 2015]. The ability to control digital structures, information availability, and information access would also influence firm boundaries or even constitute new forms of firm boundaries [Leih et al., 2015]. Assets (information) and control (through digital structures) might not any longer lie within company's boundaries but result from some forms of integration. Thus, new concepts of firm bound- 
aries may be required, such as the "open business model" [Chesbrough, 2006]. Moreover, adjacent concepts such as networks or platforms have already commanded increasing importance [Zott et al., 2011].

The new industrial revolution shifts our attention from studying simple classical supply buyer-seller relations to seeing them as a whole system and network of value creation and value capturing among co-opetitive players. Hence, the complexity of production networks depicts the number of relations, the non-linearity of such relations, the rapidly changing positions within networks, and hence the necessity of agile approaches and lean management. I4.0 also implies that competitiveness and competitive advantages arise not simply from owned assets as merely seen in the approach of 'firm as a bundle of resources' but derives from seeing it as part of digital ecosystem. At the same time, I4.0 can stimulate both, the efficiency-driven advantages and innovation-driven advantages. Whereas the first are built upon providing goods and services more efficiently - faster, cheaper, or more flexibly the latter are created by offering new improved products with novel functionalities.

\section{Firm Competitiveness from Different Perspectives}

As argued by WEF experts [WEF, 2019], those company leaders called Lighthouses, who move to implement I4.0 technologies very early, will realize the greatest benefit. The competitive advantage of front-runners will by far outweigh the higher transition costs and capital expenditures related to the early adoption of I4.0 solutions. Bearing in mind the nature, key features, and trends characteristic of the fourth industrial revolution, we refer to the industrial organization (I/O), resource-based view (RBV), and Global Value Chain (GVC) perspectives to study the sources of competitive advantage.

\section{Industrial Organization Perspective}

The I/O model shows that a firm's performance is greatly determined by the industry or business sector it is in and the factors that define the intensity of rivalry within the industrial operations corresponding to S-C-P (structure-conduct-performance). This paradigm, formulated by [Bain, 1956; Mason, 1939], demonstrates the interdependencies between the structure of the industry and the performance of companies [Bain, 1956]. It was supplemented by the initial conditions that reflected the circumstances in the demand and supply side of the market [Stead et al., 1997, p. 4]. The initial circumstances embrace technological factors among others. Thus, the aspects of I4.0 according to this old paradigm will greatly determine the structural characteristics of the industry as well as the behavior and performance of firms. To identify the impact of I4.0 upon the structural characteristics of an industry, firms can use the analytical model of the five competitive forces and the value chain concept developed by M.E. Porter [Porter, 1979]. The five competitive forces model indirectly affects the challenges and opportunities of integration that are typical for the fourth industrial revolution. The integration that is possible thanks to automation may facilitate the performance by firms of more complex and advanced yet agile roles. Related to this, the value chain concept recognizes a company as a chain of interdependent processes - primary and supportive activities - as well as sees the whole industry as a value network that is dedicated to the creation of margin for companies thanks to providing broadly understood value for customers. Both these spheres are nowadays permeated by digitalization.

\section{Resource-Based View (RBV) Perspective}

The second perspective that is useful when looking for a conceptual framework to explain the mechanism for the impact of I4.0 upon firms' competitiveness is the resource-based view (RBV) of companies (e.g., [Barney, 1991; Barney, Arikan, 2005; Wernerfelt, 2013]). The foundation of the RBV is the theory, perceiving a firm as a bundle of resources that are heterogeneous [Penrose, 1959; Teece, 2017]. The RBV postulates the necessity of resource ownership (e.g., [West et al., 2014]) to gain an advantage over competitors. To achieve and keep any competitive advantage, firms have to possess heterogenous, unique, difficult to imitate, and immobile resources which is reflected in the VIRO concept (Valuable, Inimitable, Rare and Organized). Amit \& Schoemaker [Amit, Schoemaker, 1993] pointed to the fact that industries differ in their characteristics which is why the bundle of resource creating superior performance will differ between industries, too.

\section{Global Value Chain (GVC) Perspective}

The concept of GVCs incorporates processes of fragmentation among a growing number of countries and production networks, the development of global buyers and global suppliers [Lee, Gereffi, 2015] and also contributes to our understanding of the impact of the digital revolution upon the interactions and relations between companies, in particular cooperating partners. One of the important aspects emerging from relations between entities in a GVC is the compatibility of partners and the ability to keep up with the pace of transformation. The classic five competitive forces model [Porter, 1979] can be used for examining the relations between competing and cooperating entities in the reality of

https://www.epicor.com/en/resource-center/articles/what-is-industry-4-0/, access date 15.10.2020. 
Table 1. Examples of Digitalized Models of Products and Factories

\begin{tabular}{|l|l|}
\hline \multicolumn{1}{|c|}{ Models / Tools } & Sources \\
\hline $\begin{array}{l}\text { Software for production planning and scheduling (e.g., ERP); systems for the automation and management of } \\
\text { internal logistics (e.g., RFID) }\end{array}$ & {$[$ Lasi et al., 2014] } \\
\hline New systems in the development of products and services & {$[$ Lucke et al., 2008] } \\
\hline Product Lifecycle Management Systems (PLM) & {$[$ Tchoffa et al., 2016] } \\
\hline Mobile/wireless devices for programming and the operation of equipment and machinery & {$[$ Drath, Horch, 2014] } \\
\hline Digital solutions in production (e.g., tablets, smartphones) & {$[$ Drath, Horch, 2014]. } \\
\hline Source: authors> own elaboration. & \\
\hline
\end{tabular}

the fourth industrial revolution. The literature covering the GVC concept is steadily growing. A study by Elltetö, Magasházi \& Szalavetz focuses on the topic of upgrading within GVCs [Éltetö et al., 2015] which is associated with a move from a lower valueadded activity towards a higher value-added one. Humphrey \& Schmitz [Humphrey, Schmitz, 2002] distinguished four main types of upgrading: product, process, functional, and inter-sectoral upgrading. The types of upgrading are often interlinked; sometimes they overlap or are derived from each other. Another factor that can increase profits in value chains is economies of scale. It is possible that aggregating orders and increasing the volume of sales leads to product 'downgrading', which means that larger amounts of products may generate lower value products.

\section{Firm Competitive Advantage and the New Context of Industry 4.0}

The development of I4.0 technologies is supposed to increase industrial productivity and further generally improve company performance. Firms have to think how the new technologies will impact their bargaining position within their industries and how they will reorganize their strategic capabilities. In 1985, Porter \& Millar argued that the information revolution modifies the structure of business sectors, greatly impacting the bargaining power of incumbents, their suppliers, customers, substitute providers, and potential new entrants [Porter, Millar, 1985]. It also creates new ways to outperform rivals. Thirdly, it restructures internal processes within the value chain and firm's resources and competences. The key manifestations regarding the impact of the information revolution upon firms as listed by Porter and Millar 35 years ago are still visible today. The key manifestations regarding the impact of the information revolution upon firms as listed by Porter and Millar 35 years ago are still visible today [Porter, Heppelmann, 2015].

I4.0 technologies will on one hand put pressure on companiI4.0 technologies will on one hand put pressure on companies to upgrade their strategic capabilities, and on the other, they will simultaneously contribute to that upgrading. Simulation is characteristic of I4.0 and supports virtual world testing so as to predict and evaluate the performance of systems that are analytically intractable, underlining the efficiency gains for firms thanks to the integration of sensing, computing, and control. Companies are better able to track customers' needs and procurement orders in real time. Companies are better able to track customers' needs and procurement orders in real time. I4.0 impacts the receiving and storing of components and moving them to production, along with the distribution of the products. RFID technology and intelligent applications based on user community information rather than on GPS data help to save time and avoid bottlenecks. Thus, intra- and inter-firm logistics is an area where companies may achieve substantial gains [Skapinyecz et al., 2018]. The whole value chain can operate more efficiently thanks to digitalization that modifies the intra- and inter-firm logistics, along with production processes that exploit the raw materials and sub-assemblies previously ordered. These modifications respond to the expectations that firms learn about from customers thanks to the Internet of Things and their use of social media. The Internet facilitates the emergence of a digital ecosystem embracing suppliers, manufacturers, and customers. This ecosystem is associated with the notion of a smart factory and optimized real-time new value creation networks. Factories that merit the smart concept are able to adjust their operations to constantly changing circumstances. They are no longer single production units but operate like fully automated, optimized, high-efficiency integrated units which is very much possible thanks to cloud computing. Thus, I4.0 results in the emergence of virtual, horizontally integrated Value Networks.

Big Data and Analytics Implementation can contribute to the reorganization of the sales and marketing operations of a firm and facilitate an even earlier impact upon the focus, scope, and direction of $\mathrm{R} \& \mathrm{D}$ operations within a firm. PwC [PwC, 2016] conducted a study confirming that $72 \%$ of the respondents to their survey use data analysis to improve their relationships with customers. The development of new products driven by the customers' preferences and feedback reflected in the huge pool 
of data gathered by companies may be reinforced by additive $3 \mathrm{D}$ manufacturing that enable companies to produce prototypes and individual components that support $3 \mathrm{D}$ printing. Thanks to this, firms can moderate their costs by reducing the stock which impacts their procurement operations, manufacturing processes, and internal logistics. These operations within the value chain can become more efficient, which is crucial from the perspective of the margin for a company and to further its competitiveness. Augmented Reality (AR) that combines physical real-world information with virtual information generated by computers [Craig, 2013; Schmalstieg, Hollerer, 2016] helps firms in decision making since it provides instructions on how to carry out different tasks related to warehousing and maintenance for example, thus visibly impacting the efficiency of value chain operations. Big data analytics enables businesses to discover customers' requirements, conduct market research, and support the simulation and testing of new products with $3 \mathrm{D}$ printing supporting prototyping that contributes to the shortening of the product development lifecycle [Qin et al., 2016]. Companies able to develop new products faster and launch them earlier than their competitors gain an advantage [Rubera et al., 2016]. Qin, Liu \& Grosvenor [Qin et al., 2016] describe how I4.0 solutions very much develop flexible prototyping capabilities thanks to $3 \mathrm{D}$ printing combined with cad-cam designing and flexible machining capabilities.

The competitiveness of firms may be related to efficiency-driven advantages or innovation-driven advantages. In the fourth industrial revolution the efficiency-driven advantages are the threshold advantages that may create competitive gaps between aggressively competing firms. But the gaps can disappear relatively quickly which means the advantages are temporary. A sustainable advantage is founded on knowledge and innovation. The companies need to recognize the need to reorganize their cooperation with suppliers and customers. The new I4.0 solutions enable firms to constantly communicate with their suppliers and customers; however, new collaboration models with business partners need to be developed. To fully exploit the whole set of I4.0 technologies, firms need to take care of their relationships with business partners at each stage in value creation - from research and development, procurement, and production up to sales, marketing and after-sales services. This is related to the implementation of integrated information systems, and the key resources are human resources with new qualifications to drive, produce, and maintain I4.0 systems. All qualified human resources need to be equipped with a knowledge of the IoT, robotics, blockchains, as well as manufacturing.

I4.0 solutions contribute to the integration of the various operations in a company to increase the flow of information within a firm. They also con- tribute to the integration with suppliers, customers, and other partners in the value chain. These systems support better information sharing within a company - between departments - which is crucial for the integration of data, processes, and technology in real-time that allows for the standardization of various procedures and practices [Gërvalla, Ternai, 2019]. Internal integration - vertical in nature since it means the integration of resources - is based on the connection of production management, manufacturing, and low-level PLC (Programmable Logic Controller) systems like machine controllers, sensors, and so on. The aspect of integration may be associated with organized resources that are highlighted in the RBV. The stronger vertical integration of resources increases the exclusivity of the resources, which further adds to the competitive advantage of the firm. Also, the horizontal integration that is reflected in such integration, first in operations within the firm's value chain and second with external partners, makes the position of a particular firm within its industry stronger and therefore contributes to its competitive advantage. A firm is no longer a standalone unit, but a unit integrated with other entities; and so, relationships with external partners when exploiting IT solutions adds to the flexibility and agility of each of the entities involved in the value creation process. Thus, this translates into the competitiveness of firms.

A prerequisite for competitive gains is the regulation and possible neutralization of cybersecurity threats. The I4.0 technologies involve machine controllers, sensors, manufacturing lines, and other devices that are interconnected and based on the same standards and communication protocols. This interconnectedness not only provides gains, but also new challenges and threats as well. The managers of the GVC may reorganize and diversify or develop certain parts. Innovation is not an extraordinary activity anymore but a continuous process which is crucial from the perspective of company survival. Upgrading is initiated by affiliates and reflects a bottom-up process, while governance is a top-down process triggered by the leading firm [Lee, Gereffi, 2015]. But from a different perspective, governance may be the domain of the producer or the buyer [Gereffi, Korzeniewicz, 1994]. The simple and dual typology became unsatisfactory for many GVCs since production networks are more complex. To face the complexity of production networks, Gereffi et al. [Gereffi et al., 2005] defined five types of governance: market, modular, relational, captive, and hierarchical. The first type of governance depends upon transactions where the main governing mechanism is price. Participants are not involved in any formal cooperation [Gereffi et al., 2005]. Modular governance means that suppliers follow the customers' specifications when providing products or services. The product is more sophisticated but still sufficiently modular in design. Suppliers are fully 
responsible for production and produce independently. However, they may further outsource production. Complex interactions between the supplier and the lead-firm are characteristic of relational governance. Thanks to these interactions, firms exchange tacit knowledge and knowledge spill-overs occur. The lead firm controls the highest valued activity in the chain and defines the specifications of products [Cattaneo et al., 2013]. In the case of captive governance, the lead firm is much involved in the control and monitoring of suppliers. A single lead-firm within a network creates rather unstable circumstances for small firms and these entities may sometimes feel "locked-in". Lead-firms are eager to increase the efficiency of their supply chains. Thus, they assist suppliers in upgrading. Vertical integration and managerial control among firms is then a distinguishing feature of hierarchical governance. This is necessary when products are complex, when it is difficult to codify product specifications and to find competent suppliers [Cattaneo et al., 2013].

A study by Szalavetz [Szalavetz, 2017a] investigated the impact of I4.0 - new disruptive technologies on the current geographical configuration of GVCs from the perspective of FDI-hosting intermediatelevel 'factory economies'. A crucial challenge lies in how GVC headquarters realign their strategic location choices with the emergence of the new manufacturing technologies: whether they keep their existing manufacturing facilities and upgrade them through installing I4.0 technologies (retention); consolidate and concentrate manufacturing activities in specific locations (selection); or refresh part of their activities and at the same time establish new facilities and/or outsource certain tasks (reconfiguration). Based on the interviews with Hungarian firms, the author concluded that, in the short term, retention mechanisms seem to prevail over harmful scenarios such as specific location selection or a reconfiguration. It remains open, however, whether or not this will be replaced by medium- and longerterm reconfigurations of GVC architectures. This calls for necessary reforms of the education systems in factory economies. Failure to provide adequately skilled workers and aligning training with skill demands may eventually hinder the adoption of I4.0 resulting in the relocation of activities. As summarized by [Szalavetz, 2017b], it is not I4.0 technological progress per se that may hit factory economies hard: the lack of human capital coupled with a rigid education system would make them losers in the digital transformation of manufacturing.

\section{Methodology of Our Study}

Although research on I4.0 is gaining an increasing amount of attention and studies in this area have been proliferating recently, to the best of our knowledge they still do not explicitly or fully cover the impact of the digital transformation upon the competitiveness of firms in an international cooperation context. Although exploring various aspects of I4.0, the available reports and impressive databases gathered by consultancies and private firms such as Siemens, BCG [Lorenz et al., 2015], McKinsey [Breunig et al., 2016], Polish ASTOR [Zieliński, 2016] and the initiative Przemysl-4.0.pl do not seem to focus on the questions and problems raised in our research.

The goal of our exploratory empirical study is to explore the potential impact of I4.0's adoption upon the competitiveness of firms. This research also asks about the nature of modernization as part of the global value chain in which enterprises operate. Thus, we want to take into account the likely drivers of I4.0 implementation at companies and diagnose the pervasiveness of this ongoing revolution.

The methods and techniques used in this study were determined by the research questions formulated in [Collis, Hussey, 2014]. We base our research on the case study research method into four companies. The case study method allows the results of previous research to be combined with new empirical insights [Andriopoulos, Slater, 2013]. Mowday \& Sutton [Mowday, Sutton, 1993] point out that the context of a case study functions as a unit of analysis over and above the phenomena under study; and as Cappelli \& Shere [Cappelli, Shere, 1991] indicate, this often explains some hidden non-obvious and salient aspects of the phenomena. Thus, the whole case study predisposes the researcher to study the phenomenon in its natural circumstances and further allows them to formulate new practically and empirically valid insights [Miles, Huberman, 1994]. Blumberg et al. [Blumberg et al., 2011] highlight the key features of a properly classified academic study as exploratory, descriptive, and analytical/predictive of the phenomenon it is focused on studying. In our study we focus on four cases - Viacon Polska, Amica, Kompania Piwowarska (KP), and Unilever - and this type of approach is the proper one bearing in mind the interdisciplinary character of the fourth industrial revolution. We refer to some extent to the quantitative approach using a structured questionnaire where we ask the interviewees to respond and explain particular phenomena using a five-point Likert scale. We use narrative descriptions with elements of comparison and exploit the multiple case study approach. We perceive our research as exploratory since it is to investigate the context in which the process of the implementation of the I4.0 solutions occurs. The selected cases are to help us understand the phenomenon under study [Siggelkow, 2007]. To better characterize the context for each case study, we refer to secondary data on

2 https://przemysl-40.pl/, access date 29.10.2020. 
the impact of I4.0 on companies in the new industrial reality. We rely on officially available information provided mainly on company websites and to a greater extent on the primary data and information acquired from them during direct interviews with their representatives. The selection of cases for our study was determined by the goal of the study. Purposive sampling was necessary since the adoption of I4.0 technologies and solutions differs among companies representing different business sectors as well as being more or less linked to foreign capital. The origin of the capital, and thus the location of headquarters in countries that differ in terms of their readiness for the fourth industrial revolution, seems to be an important factor explaining the greater or lesser involvement of a company in the fourth industrial revolution.

Our interviews were designed to speak for the uncertainty and complexity of the fourth industrial revolution. The aspects covered reflect namely the multifaceted and multidimensional nature of I4.0. The implementation of I4.0 is a multi-scalar phenomenon with various players involved along the GVC and different technologies used. The obtained results show that surveyed firms may indeed face the challenges that such uncertainty and complexity bring along. They seem for instance only a little familiar with I4.0-related behavior of their partners - cooperating and competing entities. Yet, they also acknowledge the existence of other framework conditions necessary for the successful implementation of digital technologies - as I4.0 comes with strings attached.

\section{Case Analysis: Industry 4.0 Adoption from the Perspective of the Studied Companies ${ }^{2}$}

Table 2 represents a general description of Industry 4.0 -induced changes across different dimensions among the studied firms, while Tables 3-6 accompanying each of the below represented cases summarize their specific features in the context of the relevant firm.

\section{ViaCon}

ViaCon ${ }^{3}$ in Poland consists of three companies: ViaCon Sp. z o.o., ViaCon Polska Sp. z o.o., and ViaCon Construction sp. z o.o. All these companies are members of the ViaCon Group, established in Sweden and Norway in 1986. ViaCon specializes in manufacturing steel and plastic pipes, galvanized plate structures for bridges and tunnels, geotextiles, geogrids, and geocomposites among other things for soil drainage and filtration, as well as grids to reinforce bituminous and asphalt pavements. All these products are manufactured in accordance with international standards - ISO 9001:2008, ISO 14001:2004, and OHSAS 18001 - and some products have the CE mark. ViaCon can be classified as an OEM with majority foreign capital and the company is listed on the stock exchange. It exports and cooperates with foreign markets by setting up wholly owned foreign subsidiaries. The company itself is a subsidiary of a multinational enterprise.

ViaCon is actively implementing a digital transformation - its employees, as in the rest studied firms, actively use digital equipment. Besides, the company uses such technologies as Big Data, Cloud Computing, Mobile Technologies, and Social Media. Systems such as customer support systems (CRM) and enterprise resource planning (ERP) are considered those most affected by the technological progress and Industry 4.0. (ViaCon exploits only some of the nine solutions that characterize Industry 4.0 - Big Data and Analytics, Cybersecurity, Cloud, abstaining currently from Autonomous Robots, Simulation (virtual mirror), Horizontal and Vertical System Integration, Industrial Internet of Things, Additive Manufacturing 3D, or Augmented Reality). ViaCon (based on agree/strongly agree) plans to restructure employment because of Industry 4.0 and it admits facing the challenge of cybersecurity and knowhow protection. ViaCon reaps advantages from cost reduction resulting from Industry 4.0, from the improvement of efficiency as well as the reduction of the time necessary to perform particular processes. The company seeks to network its value chain and admits to feeling pressure on cost reduction and recognizes legal barriers originating in Industry 4.0, which protects the company. Besides, it does expect to get some support from the government to face the threats of Industry 4.0. ViaCon dedicates particular human resources to monitoring and coping with the challenges of Industry 4.0 and has designed strategic responses to the challenges of Industry 4.0. It organizes special training sessions for improving the automation of manufacturing processes and tries to optimize the administrative processes (i.e., the flow of documents). It admits to dealing with a shortage in personnel able to cope with Industry 4.0 and the need to invest money in research and development under the new pressures presented by this paradigm. ViaCon needs to increase investment expenditures (i.e., new machines, tools, equipment).

In ViaCon's opinion, their suppliers have problems related to the reorganization of manufacturing processes or being an outsider with regard to the GVC, yet they can also see the opportunity for becoming a GVC insider thanks to the Industry 4.0 and may feel the pressure to shorten the value chain. Cer-

\footnotetext{
3 The presented findings derive from the results of our survey but they should be regarded as the authors' interpretation based on the interviewers' answers, not necessarily reflecting the firms' official stance.

${ }^{4} \mathrm{http}: / /$ viacon.pl/en, access date 29.10.2020.
} 
Table 2. Industry 4.0-Induced Changes across Different Dimensions among the Studied Firms

\begin{tabular}{|l|l|}
\hline \multicolumn{1}{|c|}{ Aspect } & \multicolumn{1}{c|}{ Description } \\
\hline $\begin{array}{l}\text { I4.0 implementation level } \\
\text { (RBV) }\end{array}$ & $\begin{array}{l}\text { New technologies adopted (tendency of patchy implementation, gradual, fragmented, though, it is } \\
\text { similar across firms) possibly reshape the firms resources (as used by staff and impacting adopted } \\
\text { managerial systems) and hence affect their competitive advantage. }\end{array}$ \\
\hline $\begin{array}{l}\text { Effects/benefits expected } \\
\text { (RBV) }\end{array}$ & $\begin{array}{l}\text { New products/new improved processes - efficiency gains enabling new/improved competitive } \\
\text { advantages (resources better allocated, more effectively used). }\end{array}$ \\
\hline Risks \& challenges (RBV) & $\begin{array}{l}\text { I4.0 implies active management in order to improve the competitive advantage of available resources } \\
\text { (capital investments and labor training are necessary). }\end{array}$ \\
\hline $\begin{array}{l}\text { Industry reshuffling } \\
\text { landscape (I/O) }\end{array}$ & $\begin{array}{l}\text { Ambiguity regarding the position of partners in industry due to I4.0, both chances and challenges are } \\
\text { acknowledged; unclear approach to the necessity of mimicking reaction due to I4.0 transformation. }\end{array}$ \\
\hline $\begin{array}{l}\text { Industry partners relations } \\
\text { (I/O) }\end{array}$ & $\begin{array}{l}\text { Ambiguity as to the governmental support, widespread pressure from partners to climb the value chain } \\
\text { and better network with each other. }\end{array}$ \\
\hline $\begin{array}{l}\text { Value chain repositioning } \\
\text { and I4.0 induced chances } \\
\text { for international expansion } \\
\text { (GVC + RBV + IO) }\end{array}$ & $\begin{array}{l}\text { Diverse opinions on actors' role in initiating the digital transformation changes; I4.0 potential for } \\
\text { streamlining international business acknowledged. }\end{array}$ \\
\hline Source: authors own elaboration. \\
\hline
\end{tabular}

tainly, in the opinion of ViaCon, the buyers feel pressed to look for new distribution channels and the uncertainty because of the possible reduction of economic advantages. Yet thanks to I4.0, they can also enjoy the opportunity to increase sales and improve competitiveness. As seen by ViaCon, the producers of substitutes reorganize their manufacturing processes and their business models. Further they also expect to improve their innovative performance. Last but not least, ViaCon improves its products and processes (i.e., a new technology allows the firm to increase efficiency). The pressure of business partners seems to make the firm move toward more knowledge-intensive functions. It performs more diverse functions and tries to go global while also moving into new business sectors.

ViaCon perceives all these changes as mainly the initiative of the firm itself. It admits also that changes are initiated by the key manufacturer in the value chain who owns the knowledge and expertise, nevertheless changes are also initiated by the buyer who controls the distribution channels and very much influences the marketing functions. The relationships of the firm with business partners are modular - the firm supplies products according to the specifications of the subcontractor. ViaCon strongly disagrees with the statement that the relationships of the firm with business partners are based on hierarchy - there are no external suppliers and cooperation takes place within the internal network of the firm. The company agrees that autonomous robots allow one to repatriate the manufacturing processes, Big data allows for better market research and making more effective investment decisions, whereas additive manufacturing allows one to shorten the value chain. Summing up, interestingly, the company does not seem to care much about the I4.0-related behavior of other firms. The lack of funds for the necessary training of employees does not seem to be a concern for the firm. The situation of firm's buyers, which seem to be very much affected by I4.0, is well-known. Relatively less clear or less known is the situation concerning the company's suppliers. Producers of substitutes, in the opinion of the firm, do not recognize digitalization as a threat for their present business models. The situation of substitute manufacturers seems to be less known for the firm. Adopting I4.0 will allow the company to develop and modernize in many diversified ways.

\section{Amica S.A.}

Amica S.A. was founded in 1945 in a small town near Poznań. Nowadays it is the largest Polish manufacturer of household appliances and one of the most recognized companies listed on the Warsaw Stock Exchange. ${ }^{4}$ Amica belongs to those OEM and end-user companies with a majority of home market (Polish) capital. It belongs to the group of large private firms with more than 250 employees listed on the Warsaw Stock Exchange. Almost 70\% of its sales are generated on export markets, while 30\% are sold on the domestic market. Amica sells its products under different brand names, depending on the region. Its strategy is based upon building strong regional brands that are recognizable in the given country. Amica aims to become one of the top three cooking appliance producers in Europe with a planned sales revenue of EUR 1.2 billion by 2023 . Amica uses all four major technologies, that is, Big Data, Cloud Computing, Mobile Technologies, and Social Media. Four different systems applied by the firm are all affected by I4.0 progress, i.e., customer support systems (CRM), enterprise resource planning (ERP), manufacturing execution systems (MESs), and energy management systems (EMS). 
Table 3. Summary of Industry 4.0-Induced Changes: ViaCon

\begin{tabular}{|c|c|}
\hline Aspect & Content \\
\hline $\begin{array}{l}\text { I4.0 implementation } \\
\text { level (RBV) }\end{array}$ & $\begin{array}{l}\text { Customer support systems (CRM) and enterprise resource planning (ERP) are the ones most affected by I4.0. } \\
\text { Some of the nine I4.0 solutions were adopted- Big Data and Analytics, Cybersecurity, Cloud; abstaining from } \\
\text { Autonomous Robots, Simulation (virtual mirror), Horizontal and Vertical System Integration, Industrial } \\
\text { Internet of Things, Additive Manufacturing 3D or Augmented Reality. }\end{array}$ \\
\hline $\begin{array}{l}\text { Effects/benefits expected } \\
(\mathrm{RBV})\end{array}$ & $\begin{array}{l}\text { Improving products and processes (i.e., new technology allows one to increase efficiency); cost reduction } \\
\text { resulting from I4.0, improvement of efficiency as well as time reduction. }\end{array}$ \\
\hline $\begin{array}{l}\text { Risks \& challenges } \\
\text { (RBV) }\end{array}$ & $\begin{array}{l}\text { Plans to restructure employment due to I4.0 } \\
\text { Challenges of cybersecurity and know-how protection admitted/acknowledged } \\
\text { Particular human resources dedicated to monitoring and coping with I4.0 challenges. } \\
\text { Strategy to face the challenges of Industry } 4.0 \text { defined. } \\
\text { Special training to improve automation provided. } \\
\text { Actions aiming at optimizing administrative processes. } \\
\text { Identified and acknowledged lack of professional workforce able to cope with Industry } 4.0 \text { and the need for } \\
\text { R\&D investments and expenditures on new machines, tools, and equipment amid I4.0 pressure. }\end{array}$ \\
\hline $\begin{array}{l}\text { Industry reshuffling } \\
\text { landscape }(\mathrm{I} / \mathrm{O})\end{array}$ & $\begin{array}{l}\text { Suppliers suffering problems related to the reorganization of manufacturing processes or being an outsider } \\
\text { of a GVC, yet with new opportunities to become an insider of the GVC thanks to the I4.0 and pressure to } \\
\text { shorten the value chain. } \\
\text { The buyers under pressure to look for new distribution channels due to the Industry } 4.0 \text { and facing } \\
\text { uncertainty because of the possible reduction of economic advantages. } \\
\text { Thanks to I. } 40 \text {, there is a possibility of enjoying the increase of sales and improvement of competitiveness. } \\
\text { Producers of substitutes reorganizing their manufacturing processes and their business models may also } \\
\text { improve their innovation performance. }\end{array}$ \\
\hline $\begin{array}{l}\text { Industry partners } \\
\text { relations }(\mathrm{I} / \mathrm{O})\end{array}$ & $\begin{array}{l}\text { Seeking to network one's own value chain, pressure on cost reduction admitted. } \\
\text { Legal barriers originating from Industry } 4.0 \text { which protect company recognized, expectations of some } \\
\text { support from the government to face the threats of Industry } 4.0 \text {. } \\
\text { The pressure of business partners causing the firm to shift to more knowledge-intensive functions; } \\
\text { performing more diverse functions and going global as well as moving into new business sectors. }\end{array}$ \\
\hline $\begin{array}{l}\text { Value chain } \\
\text { repositioning and I4.0 } \\
\text { induced chances for } \\
\text { international expansion } \\
(\mathrm{GVC}+\mathrm{RBV}+\mathrm{IO})\end{array}$ & $\begin{array}{l}\text { All these changes perceived as mainly the initiative of the firm itself. } \\
\text { Changes are initiated by the key manufacturer in the value chain who owns the knowledge and expertise, } \\
\text { nevertheless, changes are also initiated by the buyer who controls distribution channels and influences the } \\
\text { marketing functions. Modular relationships with business partners - the firm supplies products according to } \\
\text { the specification of the subcontractor. } \\
\text { Strong disagreement with the claim that the relationships of the firm with business partners are based on a } \\
\text { hierarchy - there are no external suppliers and cooperation takes place within the internal network of the } \\
\text { firm. } \\
\text { Full agreement with the statement that autonomous robots allow one to repatriate manufacturing processes; } \\
\text { big data allows one to better research the market and make more effective investment decisions, whereas } \\
\text { additive manufacturing allows the firm to shorten the value chain. }\end{array}$ \\
\hline
\end{tabular}

Out of the nine solutions typical for I4.0, six have been used at Amica: Big Data and Analytics, Autonomous Robots, Horizontal and Vertical System Integration, Industrial Internet of Things, Cybersecurity, and Cloud Computing. Amica confirms monitoring competitors' approach to Industry 4.0, operating in industries with short product life cycles, and is planning to restructure employment because of Industry 4.0. It also seeks to face the challenge of cybersecurity and know-how protection while simultaneously trying to take advantage of the reduction of costs resulting from I4.0 from the improvement of efficiency or from the reduction of the time necessary to perform particular processes. It undertakes actions to better network its value chain and admits to feeling the pressure of cost reduction. It is, however, not convinced about the need for governmental support in order to cope with the possible threats of Industry 4.0 and does seem to face the lack of funding for I4.0 training for employees. In fact, the company dedicates particular human resources to monitoring and coping with I4.0 challenges, has a defined strategy for facing these challenges, and organizes special training to improve the automation of manufacturing processes. Furthermore, Amica seeks to optimize its administrative processes (i.e., the flow of documents). It admits to facing a lack of professional workforce able to cope with Industry 4.0 and hence is investing money in research and development. Not much is known about Amica's suppliers (a number of answers indicate "neither agree nor disagree") besides the fact that they do not seem - in Amica's eyes - to feel problems related to reorganization of manufacturing processes, the lack of proper infrastructure, and pressure to make longer value chains, if then to shorten them. Concerning the firm's buyers, the Amica representative agreed that they might experience pressure to look for new distribution channels because of Industry 4.0. In addition, the company 
Table 4. Summary of Industry 4.0-Induced Changes: Amica

\begin{tabular}{|c|c|}
\hline Aspect & Content \\
\hline $\begin{array}{l}\text { I4.0 implementation } \\
\text { level (RBV) }\end{array}$ & $\begin{array}{l}\text { All four major technologies, i.e., Big Data, Cloud Computing, Mobile Technologies, and Social Media } \\
\text { adopted. } \\
\text { Four different systems applied affected by I4.0, i.e., customer support systems (CRM), enterprise resource } \\
\text { planning (ERP), manufacturing execution systems (MESs), and energy management systems (EMS). } \\
\text { Out of nine solutions typical for I4.0, six have been used: Big Data and Analytics, Autonomous Robots, } \\
\text { Horizontal and Vertical System Integration, Industrial Internet of Things, Cybersecurity, and Cloud } \\
\text { Computing. }\end{array}$ \\
\hline $\begin{array}{l}\text { Effects/benefits expected } \\
\text { (RBV) }\end{array}$ & $\begin{array}{l}\text { Cost reductions resulting from I4.0, improvement of efficiency due to I4.0, and reduction in time necessary } \\
\text { to perform particular processes. } \\
\text { Expectations regarding improvements of products offered and processes performed. }\end{array}$ \\
\hline $\begin{array}{l}\text { Risks \& challenges } \\
\text { (RBV) }\end{array}$ & $\begin{array}{l}\text { Plans to restructure employment because of Industry } 4.0 . \\
\text { Seeking to face the challenge of cybersecurity and know-how protection. } \\
\text { Committing human resources to handle I } 4.0 \text { challenges. } \\
\text { Strategy to face the challenges of Industry } 4.0 \text { in place. } \\
\text { Organization of special training to improve the automation of manufacturing processes as well. } \\
\text { Seeking to optimize the administrative processes. } \\
\text { Problem of lack of professional workforce able to cope with Industry } 4.0 \text { admitted. } \\
\text { Investing money in research and development. } \\
\text { The lack of funding for training on Industry } 4.0 \text { for employees was not an issue. }\end{array}$ \\
\hline $\begin{array}{l}\text { Industry reshuffling } \\
\text { landscape (I/O) }\end{array}$ & $\begin{array}{l}\text { Confirmed monitoring of competitors' approach to I4.0. } \\
\text { Operating in industries with short product life cycles. } \\
\text { Not much known about suppliers (number of answers indicate "neither agree nor disagree"), most likely not } \\
\text { affected by problems related to the reorganization of the manufacturing processes. } \\
\text { Expectation as to shortening of value chains. } \\
\text { Buyers experiencing pressure to look for new distribution channels due to I4.0. } \\
\text { Acknowledged uncertainty due to likely reduction of existing economic advantages. Opportunity to improve } \\
\text { the competitiveness thanks to I4.0 acknowledged. } \\
\text { Producers of substitutes reorganizing their manufacturing processes, seeing digitalization as a threat for } \\
\text { their present business models, and looking into the need to invest in innovation. } \\
\text { Expected improvements of innovation performance thanks to I4.0. }\end{array}$ \\
\hline $\begin{array}{l}\text { Industry partners } \\
\text { relations }(\mathrm{I} / \mathrm{O})\end{array}$ & $\begin{array}{l}\text { Actions undertaken to better network firm's own value chain. } \\
\text { Pressure on cost reduction admitted. } \\
\text { Not convinced about the necessity of some governmental support in order to cope with the possible threats } \\
\text { of Industry } 4.0 \text {. } \\
\text { Pressure from business partners forcing the firm to move to more knowledge -intensive functions and as a } \\
\text { consequence also to perform more functions, often more diverse functions, often globally or in new business } \\
\text { sectors. }\end{array}$ \\
\hline $\begin{array}{l}\text { Value chain } \\
\text { repositioning and I4.0 } \\
\text { induced chances for } \\
\text { international expansion } \\
(\mathrm{GVC}+\mathrm{RBV}+\mathrm{IO})\end{array}$ & $\begin{array}{l}\text { Disagreement with the statement that changes are initiated by the key manufacturer in the value chain who } \\
\text { owns the knowledge and expertise and that the relationships of the firm with business partners are simple } \\
\text { market relations created because of convenient price conditions. It, however, supports the view that the } \\
\text { changes are made due to the initiative of the firm itself and the buyer who controls the distribution channels } \\
\text { and greatly influences the marketing functions. } \\
\text { Modular relationships with business partners- the firm supplies products according to the specifications of } \\
\text { the subcontractor. } \\
\text { Autonomous robots seen as allowing for repatriation of the manufacturing processes and big data allowing } \\
\text { for better market research and making more effective investment decisions while the Internet of Things } \\
\text { allows for improving the efficiency of manufacturing processes and thus diminishes the pressure on outward } \\
\text { foreign direct investment. }\end{array}$ \\
\hline
\end{tabular}

Source: authors' own elaboration.

faces uncertainty because of the possible reduction of economic advantages, though, it also has opportunities to improve competitiveness. Amica agrees that concerning the producers of their substitutes, they in general reorganize their manufacturing processes and business models; they recognize digitalization as a threat for their present business models and the need to invest capital in innovation. Besides, they seem to expect improvements in their innovative performance thanks to Industry 4.0. Amica further expects to improve its products and its processes (i.e., new technology allows the firm to increase efficiency). The company feels the pressure of business partners forcing it to move toward more knowledge-intensive functions and as a consequence, also to perform more functions, often more diverse functions, often globally or in new business sectors. Interestingly, Amica does not agree with the statement that the changes have been initiated by the key manufacturer in the value chain who owns the knowledge and expertise and that relationships of the firm with business partners are simple market relations created because of convenient price conditions. It, however, supports the 
view that the changes are at the initiative of the firm itself and the buyer that controls distribution channels and greatly influences the marketing functions. The relationships of the firm with business partners are modular - the firm supplies products according to the specifications of the subcontractor. Amica sees autonomous robots as allowing it to repatriate the manufacturing processes and it agrees that big data allows it to better research the market and make more effective investment decisions, whereas the Internet of Things allows it to improve the efficiency of manufacturing processes and thus diminishes the pressure of finding outward foreign direct investment.

\section{Kompania Piwowarska (KP)}

$\mathrm{KP}^{5}$ was established on May 4, 1999 as a result of the merger between Tyskie Browary Książęce and Lech Browary Wielkopolski, which led to its establishment as one of the most technologically advanced brewing companies in Poland. KP now operates three breweries with a rich heritage: Tyskie Browary Książęce (established in 1629), the Dojlidy Brewery in Bialystok (1768), and Lech Browary Wielkopolski in Poznan (1895). Thanks to traditionally proven recipes, the usage of only natural ingredients, production in superbly clean breweries, and, last but not least, a skilled workforce, the firm can brew beers that are highly valued in Poland and abroad. In $2009,100 \%$ of KP's shares were acquired by SABMiller. The next ownership change followed eight years later and KP is currently part of Japan's Asahi Group. KP is an OEM with a majority of foreign capital. With more than 250 employees it belongs to the group of large firms which are listed on the stock exchange (as part of the Asahi Group - Tokyo SE). The firm exports (intercompany export) and operates on foreign markets (Asahi Group owned subsidiaries dedicated to serving foreign markets); among others in the UK, USA, Germany, Canada, and by licensing in France and the Netherlands. KP is a subsidiary of a multinational enterprise.

With respect to I4.0, Kompania Piwowarska harnesses four out of nine identified technologies: Big Data, Cloud Computing, Mobile Technologies, and Social Media. According to KP, the systems which are the most affected by technological progress and Industry 4.0 are: customer support systems (CRM), enterprise resource planning (ERP), manufacturing execution systems (MESs), and energy management systems (EMS).

New technological solutions adopted by KP encompass: Big Data and Analytics (semi-autonomous lines, packaging etc), Horizontal and Vertical System Integration, Industrial Internet of Things (to some extent), Cybersecurity, and Cloud Computing. The firm does not plan to restructure employment because of Industry 4.0, however, it is not convinced of the advantages that will allegedly be reaped from subsequent cost reductions. It does not expect to get any support from the government to face the threats of Industry 4.0 and does not invest money in research and development to deal with relevant pressures from the technological shifts. KP does monitor competitors' approaches to Industry 4.0 , it confronts the challenge of cybersecurity and know-how protection. It admits that thanks to these changes, it can take advantage of the improvement in efficiency resulting from Industry 4.0 as well as the reduction of the time necessary to perform particular processes. KP tries to network its value chain and confirms feeling the pressure on cost reduction. It also recognizes legal barriers originating from Industry 4.0 which protect the company. KP dedicates particular human resources to monitoring and coping with the challenges posed by Industry 4.0 and organizes special training to improve the automation of manufacturing processes. It tries to optimize the administrative processes (i.e., the flow of documents) and admits to facing a lack of professional workforce able to cope with Industry 4.0 and the lack of funding for relevant training for employees. The firm faces the need to increase investment expenditures (i.e., new machines, tools, and equipment). It feels that its suppliers are experiencing problems related to the lack of proper infrastructure and feels the pressure to become more of an insider of a GVC to shorten the value chain. In the opinion of KP, their buyers may feel the need for new distribution channels because of Industry 4.0. They most likely experience uncertainty because of the possible reduction of economic advantages as well as the opportunity to increase sales and improve competitiveness. Producers of substitutes for KP's offerings seem to have reorganized their manufacturing processes and their business models. They apparently recognized that capital investments in innovation are a big challenge and expect to improve innovation performance. KP improves its products and processes (i.e., new technology allows it to increase efficiency). It admits that due to the pressure of business partners, the firm has moved to more knowledge-intensive functions and has tried to go global. The ongoing I4.0-related changes are at the initiative of the firm and the relationships of the firm with business partners are the result of knowledge flows and expertise among them. Big data allows for better market research and facilitates more effective investment decisions. The Internet of Things allows the firm to improve the efficiency of manufacturing process and thus

${ }^{6}$ http://en.kp.pl, access date 29.10.2020. 
Table 5. Summary of Industry 4.0-Induced Changes: Kompania Piwowarska

\begin{tabular}{|c|c|}
\hline Aspect & Content \\
\hline $\begin{array}{l}\text { I4.0 implementation } \\
\text { level (RBV) }\end{array}$ & $\begin{array}{l}\text { The systems most affected by I4.0: customer support systems (CRM), enterprise resource planning (ERP), } \\
\text { manufacturing execution systems (MESs), and energy management systems (EMS). } \\
\text { New technological solutions adopted encompass: Big Data and Analytics (semi-autonomous - lines, } \\
\text { packaging etc), Horizontal and Vertical System Integration, Industrial Internet of Things (to some extent), } \\
\text { Cybersecurity, and Cloud Computing. }\end{array}$ \\
\hline $\begin{array}{l}\text { Effects/benefits expected } \\
\text { (RBV) }\end{array}$ & $\begin{array}{l}\text { Improving products and processes as technology enhances efficiency. } \\
\text { Not convinced about the advantage from the cost reduction resulting from I4.0. } \\
\text { Possibly taking advantage of improved efficiency resulting from I.4.0 as well as from the reduction of the } \\
\text { time necessary to perform particular processes. }\end{array}$ \\
\hline $\begin{array}{l}\text { Risks \& challenges } \\
\text { (RBV) }\end{array}$ & $\begin{array}{l}\text { No plans to restructure employment as a consequence of I.40. } \\
\text { No particular R\&D investments due to pressure from Industry } 4.0 \text {. } \\
\text { Challenges of cybersecurity and know-how protection evaluated. } \\
\text { Attempts to optimize the administrative processes (i.e., the flow of documents). } \\
\text { Facing a lack of professional workforce able to cope with Industry } 4.0 \text { and lack of funding for relevant } \\
\text { training for employees. } \\
\text { The need to increase investment expenditures (i.e., new machines, tools, equipment) identified. } \\
\text { Particular human resources dedicated to monitoring and coping with I4.0 challenges. } \\
\text { Special training to improve the automation of manufacturing processes offered. }\end{array}$ \\
\hline $\begin{array}{l}\text { Industry reshuffling } \\
\text { landscape (I/O) }\end{array}$ & $\begin{array}{l}\text { Monitoring competitors' approaches to Industry } 4.0 \text {. } \\
\text { Suppliers experiencing problems related to the lack of proper infrastructure and under pressure to become } \\
\text { more of an insider of a GVC and to shorten the value chain. } \\
\text { Buyers possibly in need of new distribution channels because of I4.0. } \\
\text { Most likely experiencing the uncertainty because of the possible economic advantage reduction. } \\
\text { Opportunity to increase sales thanks to Industry } 4.0 \text { and to improve the competitiveness also recognized. } \\
\text { Producers of substitutes reorganizing their manufacturing processes and their business models. Apparently } \\
\text { recognizing the need for capital investments in innovation because of Industry } 4.0 \text {. } \\
\text { Expectations of improved innovation performance thanks to I4.0. }\end{array}$ \\
\hline $\begin{array}{l}\text { Industry partners } \\
\text { relations }(\mathrm{I} / \mathrm{O})\end{array}$ & $\begin{array}{l}\text { No expectations concerning support from the government to face I. } 40 \text { challenges. } \\
\text { Attempts to network value chain. } \\
\text { The pressure on cost reduction confirmed. } \\
\text { Recognizing legal barriers originating in Industry } 4.0 \text { which protect the company. } \\
\text { Recognizing the pressure from business partners moving into more knowledge-intensive functions also on } \\
\text { a global scale. }\end{array}$ \\
\hline $\begin{array}{l}\text { Value chain } \\
\text { repositioning and I } 4.0 \\
\text { induced chances for } \\
\text { international expansion } \\
\text { (GVC + } \\
\text { RBV + IO) }\end{array}$ & $\begin{array}{l}\text { Disagreement with statement that the relationships of the firm with business partners arise from control - } \\
\text { captive relationships and that the firm is under the control of a stronger business partner. Further, KP does not } \\
\text { agree with the statement that the relationships of the firm with business partners are based on hierarchy - there } \\
\text { are no external suppliers and cooperation takes place within the internal network of the firm. } \\
\text { Big data enables better market research and more effective investment decisions. } \\
\text { The Internet of Things allows for improving the efficiency of the manufacturing process and thus reduces } \\
\text { pressure on outward foreign direct investment whereas additive manufacturing allows for shortening the } \\
\text { value chain. } \\
\text { Autonomous robots are not perceived as allowing for the repatriation of manufacturing processes. }\end{array}$ \\
\hline \multicolumn{2}{|c|}{ Source: authors' own elaboration } \\
\hline
\end{tabular}

diminishes the pressure on outward foreign direct investment whereas additive manufacturing allows KP to shorten the value chain. It is worth emphasizing that KP disagrees, however, that the relationships of the firm with business partners arise from control - captive relationships. It refutes the assertion that the firm is under the strong control of a stronger business partner, that the relationships of the firm with its business partners are based on hierarchy - there are no external suppliers and cooperation takes place within the internal network of the firm. It also does not see autonomous robots as allowing it to repatriate the manufacturing processes.

\section{Unilever Polska S.A.}

UNILEVER $^{6}$ is a British-Dutch transnational consumer goods company co-headquartered in London, UK and Rotterdam, Netherlands. Its products include foods and beverages (about $40 \%$ of its revenue), cleaning agents, and personal care products. It is Europe's seventh most valuable company. Unilever Polska S.A. has more than 250 employees, operates as a subsidiary of Unilever plc., and is listed on the stock exchange.

Out of the nine technologies regarded as the family of I4.0, Unilever adopts: Mobile Technologies and Social Media. Its systems that are most affected 
by technological progress and Industry 4.0 are the customer support systems (CRM) and enterprise resource planning (ERP).

Solutions harnessed by Unilever encompass Big Data and Analytics, Autonomous Robots, Cybersecurity, and Cloud Computing. Unilever, apparently, does not monitor competitors' approaches to Industry 4.0. It tries, however, to address the challenge of cybersecurity and know-how protection. It feels the pressure on cost reduction and admits to facing a lack of professional workforce able to cope with Industry 4.0. Unilever invests money in research and development under the auspice of I4.0 and confirms the issue of lack of funding for relevant training for employees. In Unilever's opinion, its suppliers face problems related to the lack of proper infrastructure and are under pressure to shorten the value chain. It disagrees, however, with the statement that buyers feel pressure to look for new distribution channels because of Industry 4.0. Producers of substitutes of Unilever products seem to recognize digitalization as a threat for their present business models and consider capital investments in innovation critical. Unilever improves its processes (i.e., new technology allows it to increase efficiency) and admits that it is under the pressure from business partners as the firm moves to more knowledge-intensive functions. The changes are initiated by the key manufacturer in the value chain who owns the knowledge and expertise. The company disagrees with the statement that the relationships of the firm with business partners are simple market relations created because of convenient price conditions and that the firm's relationships are modular meaning that the firm supplies products according to the specifications of the subcontractor. It agrees that Big Data allows for better market research and more effective investment decisions. Striking in the case of this firm is at the level of "neither nor" answers (3).

\section{Discussion of Results}

By looking closely at the governance type, we may assert the dominance of responses involving "neither agree nor disagree" indicating a lack of knowledge or neutral opinions, which seem to feature most frequently. Yet we may confirm that firms tend to have relationships with partners that are either purely market-based or modular where the firm supplies products according to the required specifications. However, two other firms disagree as their relationships arise from control which are typical captive relations or are based on a hierarchy taking place within an enterprise. This pattern most likely reflects their position within wider networks as weak with regard to the power and autonomy of surveyed firm. We may speculate that such linkages are chosen intentionally and that they mirror

\section{Table 6. Summary of Industry 4.0-Induced changes: Unilever}

\begin{tabular}{|c|c|}
\hline Aspect & Content \\
\hline $\begin{array}{l}\text { I4.0 implementation level } \\
(\mathrm{RBV})\end{array}$ & $\begin{array}{l}\text { Systems most affected by I4.0: customer support systems (CRM) and enterprise resource planning (ERP). } \\
\text { Harnessed solutions encompass Big Data and Analytics, Autonomous Robots, Cybersecurity, and Cloud } \\
\text { Computing. }\end{array}$ \\
\hline $\begin{array}{l}\text { Effects/benefits expected } \\
\text { (RBV) }\end{array}$ & Improvement of the efficiency of conducted processes. \\
\hline Risks \& challenges (RBV) & $\begin{array}{l}\text { Attempts to face the challenge of cybersecurity and know-how protection. } \\
\text { Pressure on cost reduction recognized and challenge of lack of professional workforce able to cope with I.4.0 } \\
\text { admitted. } \\
\text { Investing into R\&D under pressure of I4.0. } \\
\text { Lack of funding for I.40 trainings for employees evaluated. }\end{array}$ \\
\hline $\begin{array}{l}\text { Industry reshuffling } \\
\text { landscape (I/O) }\end{array}$ & $\begin{array}{l}\text { No monitoring of competitors' behavior in terms of I4.0. } \\
\text { Suppliers facing problems related to the lack of proper infrastructure and under pressure to shorten value } \\
\text { chain. } \\
\text { Buyers not affected by the pressure to look for new distribution channels due to I4.0. } \\
\text { Producers of substitutes recognize digitalization as a threat for their present business models and are } \\
\text { considering capital investments in innovation due to Industry 4.0. }\end{array}$ \\
\hline $\begin{array}{l}\text { Industry partners } \\
\text { relations }(\mathrm{I} / \mathrm{O})\end{array}$ & Under the pressure of the business partners moving to more knowledge-intensive functions. \\
\hline $\begin{array}{l}\text { Value chain repositioning } \\
\text { and I } 4.0 \text { induced } \\
\text { chances for international } \\
\text { expansion }(\mathrm{GVC}+\mathrm{RBV} \\
+\mathrm{IO})\end{array}$ & $\begin{array}{l}\text { The changes are initiated by the key manufacturer in the value chain who owns the knowledge and expertise } \\
\text { Disagreement with regard to statement that the relationships of the firm with business partners are simple } \\
\text { market relations created because of convenient price conditions and that the relationships of the firm with } \\
\text { business partners are modular meaning that the firm supplies products according to the specifications of the } \\
\text { subcontractor. } \\
\text { Big data allows for better market research and more effective investment decisions. }\end{array}$ \\
\hline
\end{tabular}


the firm's strategy which is aimed at maximizing the benefits arising from the implementation of I4.0 - whether it is more effective to leave certain processes to the market or internalize them according to strict rules within narrower, controlled group. The obtained results partially reflect the assumptions that a higher level of internalization goes in line with a greater knowledge pool for the company since the most valuable tacit knowledge is organizationally embedded and difficult to transfer. It contributes to the competitive advantage of firms since such knowledge is characterized by imperfect imitability and imperfect mobility [Lippman, Rumelt, 1982]. Furthermore, the firms suggest that not just internalization of particular operations provides advantages for companies, but rather smart embedding of the firm in a network - the relational capital can offset transaction costs thanks to the reciprocity and trust [Holm et al., 1999]. The lead firm in a hierarchy could provide cutting-edge technologies when it adopts the strategy of sharing instead of appropriation, though, some recent studies show that discovering new knowledge and creating innovations, also radical ones, requires rather heterarchical relations where power is decentralized and managerial competences and skills are dispersed [Gancarczyk, Najda-Janoszka, 2020]. The ambiguity of the link between the governance of the relations and knowledge as a source of competitive advantage manifests once again amid the uncertainty with which companies have to cope.

As far as the competitive advantage of the firms is concerned, we may note that three of the four studied entities revealed pressure concerning cost reduction which reflects the basic character of the efficiency-driven advantages. The challenges in cost management are general and only companies that satisfy these requirements may improve upon their advantages and move towards innovation-driven advantages. The four companies respect these challenges and implement lean management principles. At each of these companies a lean coordinator was appointed. Thus, they exploit the lean philosophy not only in an implicit but also in an explicit way. Being aware of the complexity of production networks, they tried to introduce and cultivate the relevant principles. Their passion for lean management will be further facilitated by their eagerness to implement I4.0 technologies since lean management and digitalization correspond with one another. The companies use IoT technology and Cloud Computing solutions which allow the firms to collect larger amounts of data and make traditional database infrastructure obsolete. IoT allows the firms to gather multi-dimensional data via embedded RFID (Radio Frequency Identification) devices or sensors and to share the data among machines, to analyze them by cloud computing software, which contributes to the creation of complex but at the same time lean production systems without human intervention. Two of the companies - Viacon and Amica - seem to have great potential for getting involved in $3 \mathrm{D}$ printing, as it further contributes to the lean management efforts since $3 \mathrm{D}$ printing allows one to use materials just-in-time with no waste. This trend will be continued since the technological advancements allow them to reduce costs (efficiency-driven advantages) but at the same time add to the innovation-driven advantages of the companies.

Based on the results of our interviews, we synthetized the main findings obtained by drawing on the introduced conceptual lenses. Though the firms have been adopting new technologies, it seems there is some tendency toward rather fragmented, patchy implementation, which may reflect the evolutionary nature of this fourth industrial revolution. This trend, relatively similar across firms, can possibly reshape the resource allocation and efficiency of staff and consequently, by impacting the adopted managerial systems, affect their competitive advantage. Nevertheless, at each of the studied companies, CRM and ERP systems are exploited and affected by I4.0. These companies try to move towards digital factories and to represent a holistic digitalized model of a company. In the case of Amica, these attempts are reflected within the logistic processes where strong efforts to automate the operations are visible.

Thanks to the technologies implemented and the I4.0 solutions studied, companies are able to offer new products and better shape their business processes. They can thus achieve efficiency gains resulting in new and improved competitive advantages as resources can be better allocated and/or more effectively used. The I4.0 transformation does not happen spontaneously in a vacuum - it requires that firms undertake concrete measures and this implies active management in order to improve the competitive advantage of available resources - so capital investment and labor training are necessary. At the industry level, there is a certain ambiguity regarding the position of partners due to I4.0, both the opportunities and challenges they face are acknowledged. Being aware of the greater or lesser vision of the studied firms on the challenges their suppliers, customers, and substitute providers face with regard to the fourth industrial revolution, we may assume they strive toward the creation of value networks embracing the aforementioned entities. Viacon, Amica, Kompania Piwowarska, and Unilever develop relations with these entities and equip these links with digital solutions to make the creation of value easier and to facilitate the move toward digital ecosystems. It is of course just the start of the journey. Viacon, Amica, and Unilever declared their involvement in modular relations with their clients. Their turn toward modularization means that they are able on the one hand to 
produce a basic product and then to adjust it according to the expectations of particular customers. Their involvement in modularization allows them to reduce costs (efficiency-driven advantages) and simultaneously respect specific expectations of particular customers that goes in line with innovation-driven advantages. Besides, a rather unclear approach dominates among the studied firms as to the need for mimicking or observing the reaction of other sector actors (suppliers, customers) due to the I4.0 transformation. The lack of unanimity regarding hypothetical governmental support can be diagnosed along with the more widespread and recognized pressures from partners to climb the value chain and network better with one another. Diverse opinions on actors' roles in initiating digital transformation changes can be identified among the studied companies, though the I4.0 potential for streamlining their international business is acknowledged.

\section{Conclusions}

Our study explores the reasons for and effects of the adoption of Industry 4.0 and how it influences firm competitiveness in the international context. What can be learned from a pilot study drawing on these cases? As revealed by the answers obtained, the expected impact of I4.0 is supposed to be significant and complex; though, as it seems, based more on guesses and speculation than hard data. Firms are also trying to get ready to face related challenges cost pressures, cybersecurity. They see many benefits but are fully aware of the risks involved and adopt a sober approach by not exaggerating or unnecessarily inflating their expectations. Their knowledge regarding the situation of major partners (buyers and consumers) differ, as does their familiarity with partners' progress in implementing I4.0 technologies.

The competitive advantage of a firm could be reshaped in the I4.0 era, not solely due to adopting modern solutions and advanced technologies allowing for multiple economic gains which would materialize at the company level. Competitive advantages could also be modified as a result of a sector's transformation and changing relationships with partners. Yet it seems, based on the results obtained, it is much easier for firms to predict the assumed implications in terms of the companies' own levels, whereas much ambiguity and uncertainty surrounds developments in industrial sectors.

These findings seem to correspond with the conclusions in other literature stressing the uncertainty and complexity of the digital economy in general [Kovacs, 2018], as well as difficulties with the precise measuring of the expected benefits [Dalenogare et al., 2018]. Based on a literature review (I4.0 tenets and the changing digital macroeconomic landscape; RBV, I/O strategies, and GVC perspective) we can put forward the thesis that the fourth industrial revolution emphasizes "the race to the top", giving priority to quality rather than cost reduction as a method of improving competitiveness. Since it implies the emergence of connected companies, truly linked with each other, it also heralds the disappearance of clear boundaries between them.

Companies that (try to) escape the trend towards digital networks and the optimization of value-creation chains are in danger of losing competitiveness and market relevance in the near future. Stabilizing or even increasing competitiveness will require even more efficient production procedures. We believe that our study may contribute to the upcoming research stream of Industry 4.0 and can support decision-makers in assessing their need for transformation toward Industry 4.0 practices.

We have tried to show that in the future - in the digital era - company competitiveness will be a function of Industry 4.0 maturity, which itself could be driven by various motives depending upon a firm's resources, sector characteristics, and value chain relationships with partners (whole sequence - Figure 1).

Hence, as compared to other studies which were centered on identifying the readiness and application of certain I4.0 solutions (blue part), the added value of our research can be seen in its focus on a broader perspective including the sources/drivers of this maturity or I4.0 readiness.

Based on the obtained results we posit a wider I4.0 awareness by firms as another approach to measuring Industry 4.0 readiness and maturity. We argue

\section{Figure 1. Logic of competitiveness and cross-border cooperation in the digital era}

Sources and drivers

for adopting I4.0

(RVB \& I/O)

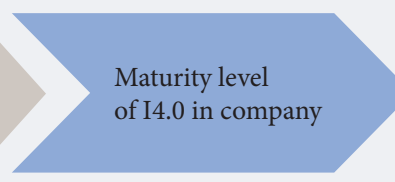
I I.0 in company
Compatibility towards foreign business partners (GVC)
Ability to

cooperate

internationally

(trade, FDI)

Source: compiled by the authors. 
there are alternative ways of approaching the problem of I4.0 maturity. Instead of simply using technology absorption or adaptation level, one may utilize the broader intelligence and awareness concerning the ecosystem as an indicator of I.40 readiness.

I4.0 will impact firms' competitiveness, though, the benefits of such adoption are anything but natural. In fact, they can materialize only under certain circumstances. Surveyed firms are aware of this and point out necessary conditions (complementary recourses, training, and investments) to be fulfilled for successful and beneficial I4.0 implementation.

Industry 4.0 adoption and its impact upon competitiveness derive from cooperation with partners. This is particularly true as digital transformation implies far-reaching interconnectedness and integration along value chains and within networks. Hence, the importance of becoming digitally conscious [Saarikko et al., 2020] and knowing partners better cannot be underestimated. Yet, as our study demonstrates, the knowledge about firms' ecosystems remains rather uncharted territory.
We are fully aware of limitations of our research, in particular the interpretation of the presented case studies and the focus on firms from just one country. We believe that these findings should be regarded as a starting point for more nuanced explorations within the grounded theory method. Such qualitative investigations based on semi-structured and in-depth interviews should verify our presuppositions and research on the impact of I4.0 upon company competitiveness using the lenses of the GVC approach. It also fits into recent calls for a modified research agenda which focuses on various aspects of GVCs in connection with the internationalization theory [Benito et al., 2019].

This paper is a result of the studies within the project of the National Science Centre in Poland. Grant no. 2016/21/B/ HS4/03030, title: Innovation performance of a foreign subsidiary and its position in the network of a multinational enterprise - the perspective of foreign subsidiaries established in Poland. The authors are grateful to Prof. Jan Polowczyk from Poznań University of Economics and Business for the support in collecting data on Kompania Piwowarska and Unilever.

\section{References}

Amit R., Schoemaker P. (1993) Strategic Assets and Organizational Rent. Strategic Management Journal, vol. 14, no 1, pp. 33-46. Available at: https://doi.org/10.1002/smj.4250140105, accessed 16.09.2020.

Andriopoulos C., Slater S. (2013) Exploring the landscape of qualitative research in international marketing: Two decades of IMR. International Marketing Review, vol. 30, no 4, pp. 384-412. Available at: https://doi.org/10.1108/IMR-03-2012-0061, accessed 16.09.2020.

Aquilante T., Bustinza O.F., Vendrell-Herrero F. (2016) Services in European manufacturing: Servinomics explained. Available at: http://bruegel.org/2016/03/services-in-european-manufacturing-servinomics-explained/, accessed 16.09.2020.

Bain J.S. (1956) Barriers to new competition, Cambridge, MA: Harvard University Press.

Barney J.B., Arikan A.M. (2005) The resource-based view: Origins and implications. The Blackwell Handbook of Strategic Management (eds M.A. Hitt, R.E. Freeman, J.S. Harrison), Hoboken, NJ: Wiley-Blackwell, pp. 123-182. Available at: https:// doi.org/10.1111/b.9780631218616.2006.00006.x, accessed 16.09.2020.

Benito G.R., Petersen B., Welch L.S. (2019) The global value chain and internalization theory. Journal of International Business Studies, vol. 50, no 8, pp. 1414-1423. DOI: 10.1057/s41267-019-00218-8.

Blumberg B., Cooper D., Schindler P. (2011) Business Research Methods, New York: McGraw-Hill Education.

Breunig M., Kelly R., Mathis R., Wee D. (2016) Getting the most out of Industry 4.0 operations, Chicago: McKinsey \& Company. Available at: https://mck.co/3lCclZB, accessed 25.01.2019.

Burmeister Ch., Lüttgens D., Piller F.T. (2016) Business Model Innovation for Industrie 4.0: Why the "Industrial Internet" Mandates a New Perspective on Innovation. Die Unternehmung, vol. 2, pp. 124-152. Available at: https://dx.doi.org/10.2139/ ssrn.2571033, accessed 15.01.2020.

Cappelli P., Sherer P.D. (1991) The missing role of context in OB: The need for a meso-level approach. Research in Organizational Behavior, vol. 13, pp. 55-110.

Cattaneo O., Gereffi G., Miroudot S., Taglioni D. (2013) Joining, upgrading and being competitive in global value chains: A strategic framework, Washington, D.C.: The World Bank.

Chesbrough H. (2006) Open business models: How to thrive in the new innovation landscape, Boston, MA: Harvard Business School Press.

Collis J., Hussey R. (2009) A practical guide for undergraduate and postgraduate students, New York: Palgrave Macmillan.

Craig A. (2013) Understanding Augmented Reality. Concepts and Applications (1st ed.), Amsterdam: Elsevier.

Culot G., Orzes G., Sartor M., Nassimbeni G. (2020) The future of manufacturing: A Delphi-based scenario analysis on Industry 4.0. Technological Forecasting and Social Change, vol. 157, art. 120092. Available at: https://doi.org/10.1016/j. techfore.2020.120092, accessed 15.08.2020.

Dalenogare L.S., Benitez G.B., Ayala N.F., Frank A.G. (2018) The expected contribution of Industry 4.0 technologies for industrial performance. International Journal of Production Economics, vol. 204, pp. 383-394. DOI: 10.1016/j.ijpe.2018.08.019. 
Drath R., Horch A. (2014) Industrie 4.0: Hit or hype? IEEE Industrial Electronics Magazine, vol. 8, no 2, pp. 56-58. DOI: 10.1109/MIE.2014.2312079.

Edquist H., Goodridge P., Haskel J. (2019) The Internet of Things and Economic Growth in a Panel of Countries. Economics of Innovation and New Technology (in press, first published online 06.12.2019), Available at: https://doi.org/10.1080/104385 99.2019.1695941, accessed 15.08.2020.

Éltető A., Magasházi A., Szalavetz A., Túry G. (2015) Global Value Chains and Upgrading: The Experience of Hungarian Firms in the Heavy Engineering and Automotive Industries. Competitio, vol. 14, no 1, pp. 5-22. DOI:10.21845/comp/2015/1/1.

Gancarczyk J., Najda-Janoszka M. (2020) Models for Development of an Innovation Network in Clusters. Problemy Zarzadzania / Management Issues, vol. 18, no 1, pp. 179-192. Available at: https://doi.org/10.7172/1644-9584.87.8, accessed 15.08.2020.

Gereffi G., Korzeniewicz M. (eds.) (1994) Commodity chains and global capitalism, London: Praeger.

Gereffi G., Humphrey J., Sturgeon T. (2005) The governance of global value chains. Review of International Political Economy, vol. 12, no 1, pp. 78-104. Available at: https://doi.org/10.1080/09692290500049805, accessed 15.08.2020.

Gërvalla M., Ternai K. ( 2019) The Impact of Industry 4.0 to the ERP Approach. SEFBIS Journal, no 13, pp. 56-62.

Hermann M., Pentek T., Otto B. (2015) Design Principles for Industrie 4.0 Scenarios: A Literature Review (TU Dortmund Working Paper 01), Dortmund: Technische Universität Dortmund. Available at: http://www.snom.mb.tu-dortmund.de/ cms/de/forschung/Arbeitsberichte/Design-Principles-for-Industrie-4_0-Scenarios.pdf, accessed 18.03.2020.

Holm D., Eriksson K., Johanson J. (1999) Value creation through mutual commitment to business network relationships. Strategic Management Journal, vol. 20, no 5, pp. 467-486. Available at: https://doi.org/10.1002/(SICI)10970266(199905)20:5\%3C467::AID-SMJ38\%3E3.0.CO;2-J, accessed 15.08.2020.

Humphrey J., Schmitz H. (2002) How does insertion in global value chains affect upgrading in industrial clusters? Regional Studies, vol. 36, no 9, pp. 1017-1027. Available at: https://doi.org/10.1080/0034340022000022198, accessed 18.03.2020.

Kagermann H., Wahlster W., Helbig J. (2013) Recommendations for implementing the strategic initiative INDUSTRIE 4.0, Frankfurt/Main: Acatech. Available at: https://www.din.de/blob/76902/e8cac883f42bf28536e7e8165993f1fd/ recommendations-for-implementing-industry-4-0-data.pdf, accessed 18.03.2020.

Kovacs O. (2018) The dark corners of industry 4.0 - Grounding economic governance 2.0. Technology in Society, vol. 55, pp. 140-145. Available at: https://doi.org/10.1016/j.techsoc.2018.07.009, accessed 18.03.2020.

Lasi H., Fettke P., Kemper H.G., Feld T., Hoffmann M. (2014) Industry 4.0. Business and Information Systems Engineering, vol. 6, no 4, pp. 239-242. Available at: https://doi.org/10.1007/s12599-014-0334-4, accessed 18.03.2020.

Lee J., Gereffi G. (2015) Global value chains, rising power firms and economic and social upgrading. Critical Perspectives on International Business, vol. 11, no 3/4, pp. 319-339. Available at: https://doi.org/10.1108/cpoib-03-2014-0018, accessed 18.03.2020.

Leih S., Linden G., Teece D.J. (2015) Business Model Innovation and Organizational Design: A Dynamic Capabilities Perspective. Business Model Innovation: The Organizational Dimension (eds. N.J. Foss, T. Saebi), Oxford: Oxford University Press, pp. 24-43. DOI:10.1093/acprof:oso/9780198701873.003.0002.

Lippman S., Rumelt R.P. (1982) Uncertain imitability: An analysis of interfirm differences in efficiency under competition. Bell Journal of Economics, vol. 13, no 2, pp. 418-438. DOI: 10.2307/3003464.

Lorenz M., Rüßmann M., Strack R., Lueth K., Bolle M. (2015) Man and Machine in Industry 4.0. How Will Technology Transform the Industrial Workforce Through 2025? Available at: https://www.bcg.com/publications/2015/technologybusiness-transformation-engineered-products-infrastructure-man-machine-industry-4.aspx, accessed 20.03.2020.

Lucke D., Constantinescu C., Westkämper E. (2008) Smart Factory - A Step towards the Next Generation of Manufacturing. Manufacturing Systems and Technologies for the New Frontier (eds. M. Mitsuishi, K. Ueda, F. Kimura), Heidelberg, New York, Dordrecht, London: Springer: Springer, pp. 115-118. Available at: https://doi.org/10.1007/978-1-84800-267-8_23, accessed 20.03.2020.

Mason E.S. (1939) Price and production policies of large scale enterprises. American Economic Review, vol. 29, pp. 61-74. Available at: https://www.jstor.org/stable/1806955, accessed 20.03.2020.

Miles M.B., Huberman M. (1994) Qualitative Data Analysis: An Expanded Sourcebook, London: SAGE.

Mowday R.T., Sutton R.I. (1993) Organizational behavior: Linking individuals and groups to organizational contexts. Annual Review of Psychology, vol. 44, pp. 195-229. Available at: https://doi.org/10.1146/annurev.ps.44.020193.001211, accessed 20.03.2020.

Nosalska K., Piątek Z., Mazurek G., Rządca R. (2019) Industry 4.0: coherent definition framework with technological and organizational interdependencies. Journal of Manufacturing Technology Management (in press, first published online 27.11.2019). Available at: https://doi.org/10.1108/JMTM-08-2018-0238, accessed 20.03.2020.

Penrose E. (1959) The theory of the growth of the firm, Oxford: Blackwell.

Porter M.E., Heppelmann J. (2015) How Smart, Connected Products are Transforming Companies. Harvard Business Review, October issue. Available at: https://hbr.org/2015/10/how-smart-connected-products-are-transforming-companies, accessed 20.03.2020.

Porter M.E., Millar V.E. (1985) How information gives you competitive advantage. Harvard Business Review, vol. 63, pp. 149-174. Available at: https://hbr.org/1985/07/how-information-gives-you-competitive-advantage, accessed 20.03.2020.

Porter M.E. (1979) The structure within industries and companies' performance. The Review of Economics and Statistics, vol. 61, no 2, pp. 214-227. DOI: 10.2307/1924589.

PwC (2016) Industry 4.0 - Building the Digital Enterprise, London: PricewaterhouseCoopers LLP. Available at: https://www. pwc.com/gx/en/industries/industries-4.0/landing-page/industry-4.0-building-your-digital-enterprise-april-2016.pdf, accessed 20.03.2020. 
Qin J., Liu Y., Grosvenor R. (2016) A categorical framework of manufacturing for industry 4.0 and beyond. Procedia CIRP, vol. 52, pp. 173-178. Available at: https://doi.org/10.1016/j.procir.2016.08.005, accessed 20.03.2020.

Rubera G., Chandrasekaran D., Ordanini A. (2016) Open innovation, product portfolio innovativeness and firm performance: The dual role of new product development capabilities. Journal of the Academy of Marketing Science, vol. 44, no 2, pp. 166-184. DOI: 10.1007/s11747-014-0423-4.

Rüßmann M., Lorenz M., Gerbert P., Waldner M., Justus J., Engel P., Harnisch M. (2015) Industry 4.0: The Future of Productivity and Growth in Manufacturing, Boston, MA: Boston Consulting Group. Available at: https://image-src.bcg.com/Images/ Industry_40_Future_of_Productivity_April_2015_tcm9-61694.pdf, accessed 24.08.2020.

Saarikko T., Westergren U.H., Blomquist T. (2020) Digital transformation: Five recommendations for the digitally conscious firm. Business Horizons (in press, first published online 15.08.2020). Available at: https://doi.org/10.1016/j. bushor.2020.07.005, accessed 24.08.2020.

Schmalstieg D., Hollerer T. (2016) Augmented Reality: Principles and Practice (Usability) (1st ed.), Boston, MA: Pearson Education.

Schuh G., Potente T., Wesch-Potente C., Weber A.R., Prote J.P. (2014) Collaboration Mechanisms to increase Productivity in the Context of Industrie 4.0. Procedia CIRP, vol. 19, pp. 51-56. Available at: https://doi.org/10.1016/j.procir.2014.05.016, accessed 24.08.2020.

Siggelkow N. (2007) Persuasion with Case Studies. Academy of Management Journal, vol. 50, no 1, pp. $20-24$.

Skapinyecz R., Illés B., Bányai Á. (2018) Logistic aspects of Industry 4.0. IOP Conference Series: Materials Science and Engineering, vol. 448 (Proceedings of the XXIII International Conference on Manufacturing, 7-8 June 2018, Kecskemét, Hungary), Article 012014. DOI:10.1088/1757-899X/448/1/012014. Available at: https://iopscience.iop.org/article/10.1088/1757899X/448/1/012014/pdf, accessed 24.03.2020.

Stead R., Curwen P., Lawler K. (1997) Industrial Economics. Theory, Applications and Policy, London: McGraw-Hill.

Štemberger M.I., Erjavec J., Manfreda A., Jaklič J. (2019) Patterns of approaches to digital transformation: An institutional arrangements perspective. Economic \& Business Review, vol. 21, no 3, pp. 467-492. DOI: 10.15458/ebr.93.

Szalavetz A. (2017a) Upgrading and value capture in global value chains in Hungary: More complex than what the smile curve suggests. Foreign Direct Investment in Central and Eastern Europe: Post-Crisis Perspectives (ed. S. Balázs), London: Palgrave, pp. 127-150. Available at: https://doi.org/10.1007/978-3-319-40496-7_6, accessed 24.03.2020.

Szalavetz A. (2017b) Industry 4.0 in 'factory economies. Condemned to be left behind? Can Central and Eastern Europe emerge from its low-wage model? (eds. B. Galgóczi and J. Drahokoupil), Brussels: ETUI, pp. 133-152. Available at: https://www.etui. org/sites/default/files/Chapter\%205_6.pdf, accessed 24.03.2020.

Tchoffa D., Figay N., Ghodous P., Expósito E., Kermad L., Vosgien T., El Mhamedi A. (2016) Digital factory system for dynamic manufacturing network supporting networked collaborative product development. Data \& Knowledge Engineering, vol. 105, pp. 130-154. Available at: https://doi.org/10.1016/j.datak.2016.02.004, accessed 24.03.2020.

Teece D.J. (2017) Towards a capability theory of (innovating) firms: Implications for management and policy. Cambridge Journal of Economics, vol. 41, no 3, pp. 693-720. Available at: https://doi.org/10.1093/cje/bew063, accessed 24.03.2020.

Wang S., Wan J., Li D., Zhang Ch. (2016) Implementing Smart Factory of Industrie 4.0: An Outlook. International Journal of Distributed Sensor Networks, vol. 12, no 1, art. 3159805. Available at: https://doi.org/10.1155/2016/3159805, accessed 24.03.2020.

Wernerfelt B. (2013) Small Forces and Large Firms: Foundations of the RBV. Strategic Management Journal, vol. 34, no 6, pp. 635-643. Available at: https://doi.org/10.1002/smj.2043, accessed 24.03.2020.

West J., Salter A., Vanhaverbeke W., Chesbrough H. (2014) Open innovation: The next decade. Research Policy, vol. 43, no 5, pp. 805-811. Available at: https://doi.org/10.1016/j.respol.2014.03.001, accessed 24.03.2020.

WEF (2019) White Paper Global Lighthouse Network: Insights from the Forefront of the Fourth Industrial Revolution, Geneva: World Economic Forum, McKinsey. Available at: http://www3.weforum.org/docs/WEF_Global_Lighthouse_Network.pdf, accessed 20.03.2020.

Zieliński M. (2016) Przemysł 4.0 w polskich fabrykach [Industry 4.0 in Polish factories]. Available at: https://www.astor.com.pl/ biznes-i-produkcja/raport-przemysl-4-0-polskich-fabrykach/, accessed 20.03.2020 (in Polish).

Zott C., Amit R., Massa L. (2011) The Business Model: Recent Developments and Future Research. Journal of Management, vol. 37, no 4, pp. 1019-1042. Available at: https://doi.org/10.1177\%2F0149206311406265, accessed 20.03.2020. 